\title{
Is Being "Smart and Well Behaved" a Recipe for Happiness in Western Australian Primary Schools?
}

\author{
John O’Rourke ${ }^{1}$, Martin Cooper $^{1} \&$ Christina Gray $^{1}$ \\ ${ }^{1}$ School of Education, Edith Cowan University, Perth, Western Australia, Australia \\ Correspondence: John O'Rourke, School of Education, Edith Cowan University, Perth, Western Australia, 6105, \\ Australia. Tel: 61-393-706-517. E-mail: j.o_rourke@ecu.edu.au
}

Received: July 2, 2012

Accepted: August 3, $2012 \quad$ Online Published: August 22, 2012

doi:10.5539/ijps.v4n3p139

URL: http://dx.doi.org/10.5539/ijps.v4n3p139

\begin{abstract}
Little is known about the relationship between students' perceptions of their behaviour and intellectual status within the classroom and their happiness. Educational practitioners consistently confront misbehaviour and academic failure; whether this is an indicator of student happiness is unclear. In this exploratory research two hundred and fifty six students were asked to self-rate their happiness via a faces scale. These students also completed a self-concept scale focussed on behavioural adjustment and intellectual and school status to determine whether these were factors that impacted on their happiness. Additionally, parents and teachers rated the participant's happiness. The findings of this research indicate that the students' perceptions of their behaviour and academic capability accounted for variance in their self-rated happiness. Both sub-scales accounted for more variance in the students' self-reported happiness than the teachers' and parents' ratings. The findings of this research are consistent with the few previous studies that attribute social factors such as belonging to childhood happiness.
\end{abstract}

Keywords: happiness, behaviour, well-being, academic, primary school

\section{Introduction}

Remember the days of the old school yard...when we had imaginings and we had all kinds of things and we laughed and needed love...yes I do... and I remember you! (Cat Stevens, 1976)

Elvin's (1965) early assertion that, "children and young people cannot learn properly if they are emotionally disturbed or deeply unhappy" (p. 173) made explicit what teachers know instinctively. Several decades on, Michalos (2008) pondered whether a relationship exists between education and happiness. He operationalised education as both the highest formal level of educational achievement one has achieved, plus non-formal and informal education (such as life experiences and social interactions). Michalos (2008) pointed out that in real terms, education impacts on health, income, life choices and job security; however, adult research on factors associated with happiness rarely mention it. Reviews on happiness and wellbeing in the academic literature such as Myers and Diener (1995), Myers (2000), Diener and Seligman (2004), and indeed the Time magazine Happiness edition (Wallis, 2004) likewise do not single out education as being a connected factor. Lyubomirsky (2008) in the How of Happiness looks towards other life factors for improved wellbeing, while Seligman (2002) in his bestselling Authentic Happiness describes education as "a means to higher income, [sic] not a means to higher happiness" (p. 59). Adults surveyed about their feelings on school, reflect on a time in their past, often with a sense of nostalgia. This current research on primary-aged students explores those receiving education services now and its impact on their happiness and wellbeing.

What is known about children's happiness is that factors such as household income and physical appearance are not significant contributors, rather social aspects such as friendships (Holder \& Coleman, 2009) and a positive view on life (O'Rourke \& Cooper, 2010) contribute more. Therefore, for those exploring happiness and the potential influence of schools and classroom teachers towards it, such findings suggest that classroom environments and teacher practice could contribute to individual student happiness. Sargeant (2010) asked nearly 400 Yr 7 students from England and Australia what they would need to make them happy and as with adult research, the dominant theme for students of both countries was the importance of relationships. While there was acknowledgment of personal and school themes, often it was things already in their lives (such as a "family that loves me [p. 419]") that enhanced happiness. An Australian participant in this research encapsulated many of the 
responses when he said: "all I need is someone who I know cares for me and I am happy" (p. 419). Holder and Coleman (2008) in their exploration of happiness for primary aged children aged 9-12 years in British Columbia also found that social factors were influential. Similarly, O'Rourke and Cooper (2010) found those children with wider friendship networks tended to be happier. Diener and Seligman (2002), in their semester-long investigation of college students, reported that students who were very happy had "rich and satisfying social relationships" (p. 83), and a positive and stable outlook on life (with few great highs or lows). Lyubomirsky (2001) identified happy individuals as being less sensitive to social comparison information (such as achievements, status, possessions, level of education), using it selectively to protect their wellbeing and self-esteem. There are other factors that impact on happiness, but when these are contextualised within schools, it is student comparisons to others that could be the lasting legacy of this time.

The present study authored by three former classroom practitioners currently working with pre-service teachers, adds to the emerging picture of children's happiness (Holder \& Coleman, 2007; Holder \& Coleman, 2009; Holder \& Klassens, 2010; O'Rourke \& Cooper, 2010) by examining whether students' perceptions of problematic behaviour and intellectual status are indicators of happiness. Additionally, the research seeks to determine whether behaviour and intellectual status are predictors of variance towards the manner in which parents and teachers rate student happiness. This is the first such research with primary-aged students and attempts to fill a gap in current understanding. The overall goal of the research is to begin a discussion that connects student behaviour and academic performance with individual happiness and wellbeing and to develop an emerging appreciation amongst educators that these behaviours require thoughtful consideration.

\subsection{Happiness and Classroom Behavior}

Student behaviour in classrooms is quite often seen as an articulation of an individual's true feelings (Albert, 1996); therefore, displays of positive behaviour and misbehaviour may be a result of many emotions. There is no research that directly links children's classroom behaviour to aspects of happiness, however, the rise in mental health issues in young people in Australian schools (Sawyer, Arney, Baghurst et al., 2000; McGorrey, Parker \& Purcell, 2006) suggests that teachers should appreciate what underlies student actions.

Why students misbehave in schools has been a focus for many researchers. While the reasons for misbehaviour are debated in the academic literature, researchers unanimously agree that it is both complex and multifaceted (Alberto \& Troutman, 2006). Hyman (1994) claims that teachers who are poorly trained, overly punitive in their classroom management methods and ineffective in providing engaging instruction for their students, can exacerbate disruptive behaviour in their classes by alienating students. Research has identified that students who are better behaved are often those that enjoy being in the class, are given choice, and understand their teacher cares for them [shown by the teacher having high expectations and respect for submitted work] (Adler, 2002; Daniels \& Arapostathis, 2000; Gransden \& Clarke, 2001; Oldfather, 1993).

Further, what appears to be critical towards student classroom behaviour is the need to belong and the ability to develop strong attachments to peers and to the school itself (Albert, 2006; Anderman, 2003; Anderson, Kerr-Roubineck \& Rowling, 2006; Newberry \& Davis, 2008; Osterman, 2000). Osterman (2000) in an extensive synthesis of the literature on school belonging, identified clearly that students who are accepted, "are more highly motivated and engaged in learning" and in turn this impacted on the "quality of relationships with others" (p. 359). Without a sense of belonging it is easy to surmise that negative experiences with peers may impair friendships and lead to loneliness and depression (Nangle, Erdley, Newman, Mason \& Carpenter, 2003). Margalit and Heiman (1998) highlight that the influence of only one friend on students with mild disabilities (MD) appears to be enough to ward off depressive symptoms. This in itself is encouragement to explore classroom behaviour and its connection with positive emotions.

Stanley, Richardson and Prior (2005) highlight the importance of early school attachments in providing "the essential environments for satisfying kinds of social interaction and healthy psychological development in the longer term" (p. 19). Further, Brendtro, Mitchell and McCall (2009) champion the importance of children developing strong connections with trusted adults to further guide and mentor them during times of need. Here they provide a snapshot of a guiding adult and the pathways for those who do not have these people in their lives;

For millennia, the image of education was a group of children gathered around a respected elder. Children crave such guidance; and if they do not receive it from adults, they learn important life lessons by default from a gang of immature peers (p. 19).

Given O'Rourke and Cooper (2010) identified that those students who are happier tend to have larger friendship groups; without positive teaching mentors, students with few friends may struggle to find positive mentorship; 
peer or otherwise. This sense of belonging and being mentored is an integral part of the "Circle of Courage" model (Brendtro, Brokenleg \& Van Bockern, 2002); whereby Brendtro et al., (2002) claim that specific universal needs (such as belonging, making choices, mastery orientations and a spirit of generosity) are required for children to thrive. Students who flourish in school are generally those who are engaged and participating in a range of school activities, both in and outside the classroom (Osterman, 2000). Stanley et al., (2005) additionally suggest: "we flourish in social contexts where we are valued and we value others, and where we can also have a sense of "the public good' to which we will contribute" (p. 23).

This appears to be commonsense, after all, most of us want to belong, but as Osterman (2000) highlights, "the concern here is how schools, as social organisations address what is defined as a basic psychological need" (p. 323). A current interpretation of Classroom Management is to ask pre-service teachers to visualise what their future classrooms will look like, sound like and feel like (McDonald, 2009). Often pre-service teachers respond with simple terms such as: happy, safe and excited. It is one thing to want to create classrooms where students feel happy, safe and excited to learn, but another to create these environments. Models such as the "Circle of Courage" are useful for teachers in understanding how children thrive and how their classrooms can be conducive to these needs. Classrooms where students feel they belong, can achieve, take on responsibility and contribute to the good of the group are surely good places to be. A student, who feels socially alienated, academically vulnerable and unable to make choices, presents very differently (Anderson, et al., 2006).

\subsection{Happiness and Intellectual Status}

So why should we be concerned with learning and happiness? Put simply, Seligman, Ernst, Gillham, and Linkins (2009) declare that "more well-being is synergistic with better learning" (p. 294). Despite this the academic literature describing students' awareness of their academic capabilities and their self described happiness has had limited attention. Aspects of student emotional states such as anxiety and loneliness are connected with child happiness (Holder \& Coleman, 2008; O'Rourke \& Cooper, 2010) and while research indicates that students with learning difficulties often present in this manner (Margalit \& Heimen, 1998; Raymond, 2008), the direct connection between the way students see themselves academically and their general wellbeing is largely unexplored. Proctor, Linley and Maltby (2009) examined 141 peer reviewed articles to present important emotional, social and behavioural constructs associated with life satisfaction in youths. In this meta-analysis those adolescents and children with extremely high life satisfaction had the highest levels of support from all sources, the least number of internalising (self put downs) and externalising behaviour (exhibitions of anger and frustration), the lowest levels of neuroticism, and significantly higher levels of academic, emotional and social self-efficacy. Conversely, Gilman and Huebner (2006) found adolescents with low life satisfaction had a poor attitude to school, poor attitude towards teachers, social stress, anxiety, depression and external loci of control.

Whether students who are academically successful or those who struggle are happy or otherwise is a moot point. Certainly, individual students become aware of their academic status by age 6-7 (Weinstein, Marshall, Sharp \& Botkin, 1987). If the underpinnings of academic self construct are developed at such an early age, then for those who by comparison appear inferior to their peers, school can be a long journey. As to whether these feelings impact on individual student's happiness may only be speculated upon, but most appreciate that life experiences associated with academic success or failure can be profound.

Learners with low self-concept (Friend \& Bursock, 2009) are often caught in a failure spiral (Raymond, 2008, p. 300 ), whereby poor academic outcomes result in lower goals and lower efforts, followed by associated failure and even lower goals and efforts. These behaviours often result in students feeling that failure is inevitable, regardless of their investment of effort and that achievement could only occur as a result of the efforts of others. Indeed, those who struggle to find connections with classroom curriculum, gradually look towards others to assist in their quest for success and are often identified as displaying "learned helplessness" (Seligman, 1975). Alternatively, those who have strong self-belief or a mastery orientation (Woolfolk, 2011) often move in an opposite direction towards a success spiral, whereby "success breeds success" (Raymond, 2008). And what becomes of these individuals? There is little evidence to suggest that academic success leads to happiness, but there is evidence that these individuals are rarely excluded in a curricular sense and often times will be given opportunities to develop their skills further. When students feel included and find success, they begin to take more control of their lives (Osterman, 2000; Seligman, 1975).

Research has identified that teachers are more likely to view students with a mastery orientation as "harder working, have better in-class social skills [sic] and more likely to succeed than low-mastery students" (Schraw \& Aplin, 1998, p. 218). Those who have poor academic self-concept and associated failure experiences can often times be excluded or streamed and this may ultimately impact on the choices they can make in the future (Pinto, 
2006). To feel separated from others based on academic ability appears to have the capacity to impact on individual happiness. The following conversation included in O'Rourke and Houghton's (2009, p. 31) exploration of the experiences of adolescents with MD in inclusive classrooms, perhaps captures the feelings associated with exclusion:

Interviewe: Do you like working in groups?

John: Mmm sometimes.

Interviewer: When don't you like it?

John: Hmm I don't know.

Interviewer: So when do you like it?

John: When it's a fun activity.

Interviewe: What if you had to work in a group where you didn't know the people well?

John: Yes it's tricky.....It's not that good because I don't belong.

Interviewe: How? Is it scary?

John: I don't know.

Interviewe: Is it because of what people might think?

John: Probably.

Interviewe: Well what might they think?

John: That I don't know anything or something like that.

Teachers need to imagine what it is that students who struggle may feel. Noddings (2003) discusses that teacher focus should not be on students being happy all the time, but that it should be a major aim of education. She emphasises its importance by simplifying an overview of the interconnection, "happy students learn better than unhappy students.....and happy people, are rarely mean, violent or cruel” (p. 2). Huebner, Gilman and Suldo (2006) report that students with high levels of happiness display more appropriate behaviour, obtain higher school grades, have better peer and teacher relationships and engage at a greater level in classroom and extra-curricular activities (p. 3). Finally, O'Rourke and Houghton (2008) explored 28 classroom variables to determine what students with MD found helpful in terms of academic and social outcomes; the most positive of these for academic outcomes was the teacher making the subject "interesting and enjoyable". Classrooms where teachers make student enjoyment a learning objective must surely impact on student behaviour and feelings.

\section{Method}

This paper is based on a larger study. A full exposition of the data from this research is available in O'Rourke and Cooper (2010). A smaller cohort exists for this exploration of the Behavioural Adjustment and Intellectual and School Status subscale of the Piers-Harris 2, as three schools failed to complete these scales.

\subsection{Participants}

Primary schools in the metro area of Perth, Western Australia $(N=817)$, both in the public and private school systems, were given information letters, consent forms and survey forms to be viewed by their parents/guardians/caregivers. Of these 325 consented (37.3\%) to participate. Thirteen students (4\%) were excluded from the research either because their forms were incomplete or they were away at the time of data collection. The final number of students involved in the study was 312. Of these an administrative error resulted in three schools not completing aspects of the Piers-Harris 2 reported herein and as such the cohort described here is 256 students.

\subsection{Survey Materials}

Students completed three questionnaires to indicate their happiness levels; the Piers-Harris 2 Children's Self-Concept scale Happiness and Satisfaction sub-scale (Piers \& Hertzberg, 2002), the children's questionnaire (made up of a variety of factors used as indicators of happiness i.e., perceptions of wealth, number of friends etc) and a faces scale. In addition, parents completed a questionnaire focussed on demographic and lifestyle factors, with questions presented in a Likert-style format similar to the children's questionnaire and a faces scale describing the happiness of their own child. Finally, teachers were asked to describe how happy the students involved in the research were, again using a faces scale.

Each of these measures will be presented below. 
a) The Piers-Harris 2 (PH2) is made up of six sub-scales designed to assess components of self-concept. In this current research, three sub-scales were used: Behavioural Adjustments, Intellectual and School Status, and Happiness and Satisfaction. The "Behavioural Adjustments" sub-scale measures admissions or denial of problematic behaviours (Piers \& Herzberg, 2002, p. 24). It contains items such as "I am well behaved at school", "It is usually my fault when something goes wrong" and "I am often mean to other people". The "Intellectual and Social Status" sub-scale measures "a child's assessment of his or her abilities with respect to intellectual and academic tasks" (Piers \& Herzberg, 2002, p. 24). It contains items such as "I am good in my schoolwork", "I am slow in finishing my schoolwork" and "my classmates in school think I have good ideas". Finally, the "Happiness and Satisfaction" sub-scale aims to elicit indications of happiness, with items such as "I am easy to get along with" and "I am a happy person". The PH2 has been used in many settings and with varied groups of students, including those with additional needs, ethnic minorities, and students ranging from 6 through to 20. It consistently demonstrates high internal reliability, with the total scale averaging an alpha of 0.91 and consistently reliable alphas through the subscales for all participant age groups (Piers \& Herzberg, 2002). In this present study the sub-scale alpha for Behaviour Adjustment was 0.74 and for "Intellectual and Social Status" was 0.86 , both indicating reasonable reliability.

b) The faces scale was a replication of the scale used by Holder and Coleman (2008; 2009; Holder \& Klassen, 2010) and comprised a seven-item Likert type scale (see Table 1) showing a range of simple faces that ranged from "very happy" to "very sad". These were used to address the question; "How happy are you most of the time"? Parents similarly rated their child's happiness using the same faces scale and addressed the question "How happy is your child most of the time ?" In line with the approach taken in Holder and Coleman's (2008), teachers rated students who participated in the study using a similar faces scale, but completed it by answering two questions; "How happy is (student's name) when she/he is doing normal work in your classroom?" and "How happy is (student's name) when she/he is doing fun activities ?" As some students appear much happier when engaged in less traditional academic classes (O'Rourke \& Houghton, 2009), the teacher's measure of individual student happiness was the average of the two responses. Table 1 shows the data from the faces scale in this research.

c) Children's questionnaire contained demographic and lifestyle questions similar to those used in adult research and recently explored in children's research on happiness (De Neve \& Cooper, 1998; Holder \& Coleman, 2008; Lyubomirsky \& Lepper, 1999; Myers \& Diener, 1995). The questionnaire sought to determine whether students were popular, confident, extroverted and optimistic; all indicators of children's happiness.

d) The Parent questionnaire was a brief survey providing personal demographic information on the parent and child, such as gender of person completing the survey, who the child predominately lives with, marital status of parents, age of mother and father, gross family income and "how many hours does your child watch tv?" Again this was a Likert type scale, with a range of responses available.

Of the parents who consented to participate in the research, $87 \%$ were female and $13 \%$ male. The gender breakdown of students was $56.6 \%$ girls and $43.4 \%$ boys and these were drawn from 11 schools and 28 classrooms. The students ranged in age from 9 years through to 12 years. The mean age of the Year 4 cohort was $M=9.54 S D=0.408$ and the Year 6 cohort was $M=11.11 S D=0.412$. To ensure a broad sample, the researchers selected schools with a wide range of socio-economic levels, with $13 \%$ within the $0-40 \mathrm{k}$ gross income range, and $20 \%>150 \mathrm{~K}$.

Seventy four percent of parents within this research were married, $5 \%$ were in defacto relationships, $3 \%$ were separated, $8 \%$ were single, $3 \%$ were divorced and $1 \%$ widowed.

\subsection{Procedure}

Upon gaining appropriate ethics clearances, schools from a variety of inner city and suburban locations, representing a variety of socio-economic areas, were posted a package describing the proposed research and current understanding of happiness. Approximately 10 days later, a phone call was made to the School Principals and for those receptive towards involvement in the research a face-to-face interview with the first author was organised. Where both the Principal and classroom teachers of a school agreed to participate, a letter was sent home to parents of students in $\mathrm{Yr} 4$ and 6 requesting consent and the completion of the parent questionnaire. It is worth adding, that the responses from School Principals were mixed, many describing the research as nebulous and that their teachers would not be interested in participating in such a vague study. On the other hand, other School Principals were enthusiastic and connected the research goals with their own sense of developing positive school communities.

Only the students who returned the consent form and parent questionnaire were included in this research. When 
these forms were returned, the main researcher visited the school and coded the participants against the class lists for later data analysis. During this visit the main researcher organised a time to collect data and met with individual classroom teachers to discuss aspects of the research. Data collection generally occurred within one week of parent returns depending on the school program. During the student data collection, the teacher's faces scale was collected for those students involved. A set explanation of the format, goals of the research and the idea that we were hoping to measure how they felt "most of the time" was presented at each school. Each data collection session was completed in 20-30 minutes, without assistance of teachers or support staff.

\section{Results}

A total of 256 questionnaires were entered into an SPSS spreadsheet for data analyses. A one-way ANOVA was conducted to determine if there was a statistically significant difference on any of the four happiness scores between groups of Year $4(n=195)$ and Year $6(n=117)$ primary school children (see Table 1). No significant differences were revealed.

\subsection{Happiness Ratings}

Using the face scales, children were rated happy by themselves (i.e., ChildOwnFace), their parents (i.e., ParentChildFace), and their teachers (i.e., TeacherChildFace). At least $88 \%$ of the child responses, above $96 \%$ of the parent and $90 \%$ teacher responses were within the three happiest categories (see Table 1). The fact that the parents rated their children consistently higher than the children and teachers is worth some consideration.

Table 1. Percentage of respondents within each category of the three Faces Scales

\begin{tabular}{|c|c|c|c|c|c|c|c|}
\hline \multicolumn{8}{|l|}{ Score } \\
\hline Respondent Group & 1 & 2 & 3 & 4 & 5 & 6 & 7 \\
\hline & 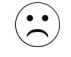 & $\because$ & $\because$ & $\because$ & $\because$ & $\because$ & 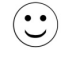 \\
\hline ChildOwnFace & 0.4 & 0.4 & 3.1 & 8.2 & 20.3 & 45.7 & 21.9 \\
\hline ParentChildFace & 0.4 & 0.0 & 0.8 & 2.3 & 15.2 & 54.3 & 27.0 \\
\hline TeacherChildFace & 0.0 & 0.8 & 0.0 & 9.3 & 25.0 & 45.0 & 19.9 \\
\hline
\end{tabular}

Note. Percentage of children's self-ratings (Child Own Face), parents' rating of their children (Parent Child Face), and teachers' ratings of the children (Teacher Child Face), in each of the seven response options on the Face Scale.

The results were similar to Holder and Coleman's (2008) research, although 14\% more of the Canadian students (of similar age) placed themselves in the highest category of happiness. For a more thorough analysis of the faces scales used in this research see O'Rourke and Cooper (2010).

\subsection{Behaviour and Intellectual Status Sub-scales}

In line with Holder and Coleman (2008; 2009) and O'Rourke and Cooper (2010); multivariate regression analyses was used to explore the relationship between the student's self-reported measure of happiness (Child-own Faces Scale) and the individual items within the BEH and INT sub-scales. The results (see Table 2) highlighted that the BEH and INT sub-scales accounted for upwards of $25 \%$ in the variance of self-reported happiness on the children's faces scale. Within the sub-scales several items were significant contributors to this variance.

Table 2. Variance in ChildOwnFace (COFS) predicted by the Piers-Harris 2 sub-scales

\begin{tabular}{|c|c|c|}
\hline $\begin{array}{l}\text { Piers-Harris } \\
\text { Sub-scale }\end{array}$ & $\begin{array}{l}\text { Variance in happiness (COFS) } \\
\text { predicted by sub-scale }\end{array}$ & Piers-Harris $2-$ significant items \\
\hline $\begin{array}{l}\text { Behaviour } \\
\text { Adjustment } \\
\text { Sub-scale }\end{array}$ & $25.5 \%$ & $\begin{array}{l}\text { Item 12: I am well behaved at school. } \\
\text { Item 13: It is usually my fault when something goes } \\
\text { wrong. } \\
\text { Item 36: I hate school. } \\
\text { Item 58: I think bad thoughts. }\end{array}$ \\
\hline $\begin{array}{l}\text { Intellectual and } \\
\text { Social Status } \\
\text { Sub-scale }\end{array}$ & $25 \%$ & $\begin{array}{l}\text { Item 12: I am well behaved at school. } \\
\text { Item 18: I am good at my school work. } \\
\text { Item 26: My friends like my ideas. }\end{array}$ \\
\hline
\end{tabular}


This is comparable to the variance of other elements of the PH2 such as "Freedom from Anxiety" and "Popularity" identified in O'Rourke and Cooper (2010); although less than the combined items of the PH2 representing negative relationships with peers (32\%) in Holder and Coleman (2009).

\subsection{Perceptions of Behaviour}

To determine whether there was a statistical difference between the mean happiness scores of students who rated themselves in the low range and those in the average and above average range of the BEH, an independent t-test was conducted (see Table 3 ). There was a statistically significant difference $(p<0.01)$ between the means of the happiness scores for the Child's own Faces Scale (CFS). The same process was followed to compare these groups by way of mean score for the Teacher's own Faces Scale (TFS) and the Parent's Faces Scale (PFS). A significant difference $(\mathrm{p}<0.01)$ was identified with TFS, however, this was not evident for the PFS.

Table 3. Differences in self-reported happiness for students, parent view and teacher view for those in the low versus average/above average range for the behavioural adjustment sub-scale

\begin{tabular}{lllll}
\hline & Behavioural & $\mathrm{N}$ & Mean & Std. Deviation \\
\hline Child FS** & Low Group & 29 & 4.76 & 1.354 \\
& Others & 227 & 5.85 & .949 \\
Parent FS & Low Group & 29 & 5.86 & 1.125 \\
& Others & 227 & 6.05 & .783 \\
Teacher FS** & Low Group & 29 & 5.5517 & .95753 \\
& Others & 227 & 6.0110 & .83274 \\
\hline
\end{tabular}

The individual items on the BEH sub-scale were often positively correlated with the four measures of happiness used, in many cases significantly so (see Table 4). The only item that was highly significant for all four measures of happiness was; I am often in trouble. While the items appeared to be good indicators of variance for the child's self-reported happiness, they were not always as positively correlated for the teachers and parents perceptions of child happiness. The parent's view of their own child's happiness showed little connection with the behavioural factors identified in this sub-scale.

Table 4. Pearson product-moment correlations between happiness measures and the BEH sub-scale (Note 2)

\begin{tabular}{lllll}
\hline Item names & HapPH2 & COF & PCF & TCF \\
\hline PH13: Usually my fault & $0.26^{* *}$ & $0.15^{*}$ & 0.12 & 0.08 \\
PH14: Cause trouble & $0.36^{* *}$ & $0.21^{* *}$ & 0.04 & 0.1 \\
PH18: Good at schoolwork & $0.36^{* *}$ & $0.32^{* *}$ & $0.14^{*}$ & $0.18^{*}$ \\
PH19: Do many bad things & $0.35^{* *}$ & $0.27^{* *}$ & $0.17^{* *}$ & $0.13^{*}$ \\
PH20: Behave badly at home & $0.25^{* *}$ & $0.21^{* *}$ & $0.14^{*}$ & $0.15^{*}$ \\
PH27: Often in trouble & $0.34^{* *}$ & $0.24^{* *}$ & $0.25^{* *}$ & $0.19^{* *}$ \\
PH30: Parents expect too much & $0.31^{* *}$ & $0.26^{* *}$ & $0.13^{*}$ & $0.18^{* *}$ \\
PH36: Hate school & $0.24^{* *}$ & $0.28^{* *}$ & 0.09 & $0.22^{* *}$ \\
PH38: Often mean & $0.32^{* *}$ & $0.26^{* *}$ & 0.09 & 0.1 \\
PH45: Get into fights & $0.33^{* *}$ & $0.22^{* *}$ & 0.03 & 0.1 \\
PH48: Family disappointed & $0.34^{* *}$ & $0.23^{* *}$ & 0.12 & $0.17^{* *}$ \\
PH58: Bad thoughts & $0.24^{* *}$ & $0.22^{* *}$ & 0.1 & $0.13^{*}$ \\
PH 60: Good person & $0.36^{* *}$ & $0.21^{* *}$ & 0.06 & $0.15^{*}$
\end{tabular}

Note. ${ }^{*} \mathrm{p}<0.01 ; * \mathrm{p}<0.05$. HapPH2 $=$ Piers-Harris 2 Happiness \& Satisfaction sub-scale; COF $=$ Child Own Face ratings; $\mathrm{PCF}=$ Parent Child Faces rating; $\mathrm{TCF}=$ Teacher Child Faces rating. 


\subsection{Perceptions of Intellectual and Social Status}

As with the BEH sub-scale the mean happiness scores of students who rated themselves in the low-range and those in the average and above-average range of the INT were compared using a t-test (see Table 5). There was a statistically significant difference $(\mathrm{p}<0.01)$ between the means of the happiness scores for the CFC, TFC and PFC when comparing those students with a low INT score (as defined in the Piers-Harris 2 documentation) and the remainder of the students for each of the face scales.

Table 5. Differences in self-reported happiness for students, parent view and teacher view for those in the low versus average/above average range for Intellectual and Social Status sub-scale

\begin{tabular}{lllll}
\hline & PH2: Intellectual and Social & & & \\
& Status (INT) sub-scale & $\mathrm{N}$ & Mean & Std. Deviation \\
\hline Child FS** & Low Group & 13 & 4.23 & 1.589 \\
& Others & 243 & 5.80 & .963 \\
Parent FS** & Low Group & 13 & 5.38 & 1.502 \\
& Others & 243 & 6.06 & .766 \\
Teacher FS*** & Low Group & 13 & 5.1154 & 1.10215 \\
& Others & 243 & 6.0041 & .82195 \\
& Others & 243 & 19.16 & 3.065 \\
\hline
\end{tabular}

The individual items on the INT sub-scale were also often positively correlated with the four measures of happiness used (see Table 6). There were several items that were highly significant for all four measures of happiness; I am smart; my friends like my ideas; and I forget what I learn. Unlike the BEH the items on the INT appeared to be a more consistent indicator of happiness for the students, parents and teachers.

Table 6. Pearson product-moment correlations between happiness measures and the INT sub-scale (Note 3)

\begin{tabular}{lllll}
\hline Item & HapPH2 & COF & PCF & TCF \\
\hline PH5: I am smart & $0.31^{* *}$ & $0.26^{* *}$ & $0.20^{* *}$ & $0.22^{* *}$ \\
PH7: I get nervous & $0.20^{* *}$ & 0.11 & 0.10 & $0.13^{*}$ \\
PH12: Well behaved at school & $0.39^{* *}$ & $0.31^{* *}$ & $0.24^{* *}$ & 0.06 \\
PH16: Important member of family & $0.31^{* *}$ & $0.16^{*}$ & $0.13^{*}$ & 0.11 \\
PH18: Good in my schoolwork & $0.36^{* *}$ & $0.32^{* *}$ & $0.14^{*}$ & $0.18^{* *}$ \\
PH21: I am slow in finishing my schoolwork & $0.18^{* *}$ & $0.22^{* *}$ & 0.07 & $0.14^{*}$ \\
PH22: Important in my class & $0.26^{* *}$ & $0.15^{*}$ & $0.13^{*}$ & $0.15^{*}$ \\
PH24: I can give a good report & $0.20^{* *}$ & $0.15^{*}$ & $0.18^{* *}$ & $0.17^{* *}$ \\
PH25: In school I am a dreamer & $0.19^{* *}$ & $0.19^{* *}$ & 0.03 & 0.08 \\
PH26: My friends like my ideas & $0.40^{* *}$ & $0.27^{* *}$ & $0.23^{* *}$ & $0.27^{* *}$ \\
PH34: I often volunteer & $0.25^{* *}$ & $0.17^{* *}$ & $0.13^{*}$ & 0.03 \\
PH39: My classmates think I have good ideas & $0.43^{* *}$ & $0.24^{* *}$ & $0.17^{*}$ & $0.27^{* *}$ \\
PH43: I am dumb about most things & $0.24^{* *}$ & $0.17^{* *}$ & 0.10 & $0.16^{* *}$ \\
Ph50: I will be an important person & $0.26^{* *}$ & $0.17^{* *}$ & $0.14^{*}$ & 0.05 \\
PH52: I forget what I learn & $0.25^{* *}$ & $0.23^{* *}$ & $0.17^{* *}$ & $0.19^{* *}$ \\
Ph55: I am a good reader & 0.08 & $0.13^{*}$ & -0.01 & -0.05
\end{tabular}

Note. ${ }^{* *} \mathrm{p}<0.01 ; * \mathrm{p}<0.05$. HapPH2 $=$ Piers-Harris 2 Happiness \& Satisfaction sub-scale; COF $=$ ChildOwnFace ratings; $\mathrm{PCF}=$ Parent Child Faces rating; $\mathrm{TCF}=$ Teacher Child Faces rating. 


\section{Discussion}

The Associated Press \& MTV survey (2007) of 1280 youth (618 in the 13-17 age group) describe 13\% as unhappy with school and $12 \%$ unhappy about grades; for the majority of those surveyed school and school performance generally elicited positive emotions or had no influence. The current research described herein, sought to explore a younger cohort and examine their self-perceptions of behaviour and academic status, to determine whether these impacted on their self-reported happiness. Comparison of the results from the "Behavioural Adjustment" (BEH) and "Intellectual and School Status" (INT) sub-scales of the Piers-Harris 2 Self-Concept scale (Piers \& Herzberg, 2002) and four measures of happiness, allowed the authors to appreciate the variance accounted for by these variables. Further, the study explored whether those students who were positive about their perceptions of behaviour and intellectual status, were identified as happier by teachers and parents than those with more negative perceptions. As this is an emerging area of research, the findings of this study merely present an initial foray into the discussion, but the data presented allows researchers and practitioners to consider implications of school and classroom practice.

In the main, the 256 students involved in this research were happy with $88 \%$ rating themselves in the highest three places on the faces scale. The levels of self-reported happiness of these same aged students were similar to the students in Holder and Coleman (2008), although more students in the Canadian research put themselves in the top level of the faces scale (O'Rourke \& Cooper, 2010). Most students in the current study were happy and generally optimistic about life and their ability to perform in school. Of those who identified themselves as very happy (in the top segment of the faces scale), all declared that they would "do well at school this year". Further, $98 \%$ of these individuals were also in the above average range for the BEH and INT sub-scales of the PH2. It appears within this survey those students who were happiest saw themselves as being in control within their school and home environments.

\subsection{Student Behaviour and Happiness}

Twenty five percent of the variance predicted in self-reported happiness of students in this study could be accredited to the BEH sub-scale. Additionally, the items of the BEH were generally positively correlated to all measures of happiness used in this research. The variance predicted is similar to that of the PH 2 "Freedom from Anxiety" and "Popularity" sub-scales (O'Rourke \& Cooper, 2010) and highlights that aspects of temperament appear to be indicators of happiness with primary-aged students. The findings in this research are also consistent with Holder and Coleman's (2009) exploration of select social items of the PH 2.

The BEH accounted for considerably less variance in the parent and teachers perception of these students happiness. As this is the first research to explore connections between classroom and home behaviour with happiness, it is difficult to generalise the findings, but positive and negative affirmations to the significant sub-scale items for students such as; "I am well behaved", "It is usually my fault when something goes wrong", "I hate school", and "I think bad thoughts", presents a profile that many teachers and parents can recognise. Given that $50 \%$ of those in the low range of the BEH sub-scale within this study identified themselves as unhappy, suggests that many of these cohorts are not thriving within schools and this is cause for concern.

Making comparisons between these findings and adult happiness literature is difficult, however, several studies examining youth happiness (Baker, Lilly, Aupperlee \& Patil, 2003; Gilman \& Huebner, 2006; Park \& Peterson, 2006; Proctor, Linley \& Maltby, 2009) parallel trends indicated in this study. Gilman and Huebner (2006) revealed that youth (from Yr 6-12) reporting high levels of life satisfaction were more likely to have positive relationships, less intrapersonal stress, higher levels of hope and personal control than those with low life satisfaction; positive affirmations in the PH2 appear indicative of these individuals. Diener and Seligman (2002) in their exploration of college students suggest that "there is no single key to high happiness" (p. 83); however, low neuroticism and relatively low levels of psychopathy appear important. The PH2 manual presents descriptors of typical students within the three score ranges of the sub-scales; students in the low range on the BEH sub-scale are described as "frequently causing trouble and as being unable to adhere to the standards of conduct set by their parents and/or teachers" (Piers \& Herzberg, 2002, p. 24); given the repercussions for children unable to meet recognised school and home standards of behaviour, it is not surprising that this sub-scale should contribute to variation in self-reported happiness by students.

What became apparent within this study is that while the PH2 was positively correlated to measures of the students' happiness and that of the teachers, these were not replicated consistently by the students' parents. Additionally, while there were significant differences between the mean happiness scores for the CFS and TFS for those in the low range for $\mathrm{BEH}$ when compared against those in the average and above average range; this was not evident for the PFS. It appears for parents the behaviour of their children may not impact on their 
perceptions of their happiness. Drolet, Paquin and Soutyrine (2007) identified that parents often see the conduct of their poorly behaved children through a different focus and may have different explanations for what is happening at school. The findings of this study suggest their parents and their children having conflicting views on how behaviour impacts on their happiness, and a deeper appreciation of this area appears warranted.

\subsection{Student Intellectual Status and Happiness}

Similar, to the BEH, the Intellectual and Social Status (INT) also accounted for considerable variance (25\%) towards measures of happiness. Like the BEH, the INT accounted for considerably less variation for the TFS (15\%) and the PFS (14\%). However, unlike the BEH, the items of the INT were consistently positively correlated with all measures of happiness in this study. Similarly, when those in the low range of the INT were compared against those in the average to above range, there was a significant difference on the means for students, parents and teachers. In contrast to behaviour, one can surmise from this that poor academic performance is considered by all to impact on happiness.

While the INT item "I am good in my schoolwork" was significant and a clear indicator of academic status, the other significant item of this sub-scale, "my friends like my ideas", appears linked to social aspects of the classroom. The currency of social connections is consistently associated with children's happiness (Dockery, 2005; Gilman \& Huebner, 2006; Holder \& Coleman, 2008; 2009; Holder \& Klassen, 2010; O’Rourke \& Cooper, 2010 ) and perhaps this item is a clearer indicator of wellbeing than others such as, "I forget what I learn", "I am slow in finishing my schoolwork" or "I am a good reader". Although there are limited studies that focus on primary students, Suldo, Riley and Shaffer (2006) point out in their review of academic correlates and life satisfaction for adolescents, that IQ, grade point averages and diagnosed learning disabilities were not strong indicators of life satisfaction, while care and support was a factor. Further, Natvig, Albrektsen and Qvarnstrom (2003) in their exploration of whether academic competence was associated with adolescent happiness, found no such evidence, rather their research pointed to social skills (as in the ability to cope with bullying, making friends and getting involved in school activities) as being strongly connected. Finally, Van Petegem, Aelterman, Rosseel and Creemers (2007) identified that student wellbeing is directly affected by interpersonal relationships that exist with teachers.

\subsection{Implications for Schools and Classrooms}

The findings from the current research provide initial evidence that behaviour and intellectual status may be associated with happiness among primary students. The small group within this study, who described themselves as unhappy, tended to be the same students in the low range in the PH2 sub-scales measuring behaviour and intellectual status. The WA Curriculum Framework (1998) highlights a commitment to celebrating student strengths, whereby, "each person should acknowledge his or her own uniqueness and be encouraged to develop self-respect and dignity" (p. 1). For teachers working under this framework, it is expected that the needs of students who are failing to thrive in classrooms are addressed. While there are a variety of classroom interventions that may address individual student behaviour and their capacity to engage with the curriculum, student happiness and wellbeing may require more holistic interventions.

One such consideration currently being explored in schools is Positive Education (Seligman, 2008; Seligman, Ernst, Gillham, Reivich, \& Linkins, 2009). The approach advocated by Seligman and others, embeds aspects of positive psychology into academic classrooms, pastoral situations and even on the sporting field (Seligman et al., 2009, p. 305). A particular focus is exploring virtues and strengths (Peterson \& Seligman, 2004). These include six virtues and 24 character strengths such as creativity, curiosity, open-mindedness, love of learning and perspective (Seligman, Steen, Park \& Peterson, 2005, p. 412). It is via a deeper appreciation of individual strengths that students are encouraged to address classroom and school obstacles. Initial research at Geelong Grammar School (GGS), has found positive education improved strengths associated with learning and in specific situations academic achievement compared to those not in the program (Seligman et al., 2005).

Another approach that primary classroom teachers could contemplate is a focus on engaging curriculum. Not only does student engagement and corresponding self-determined behaviour (Ryan \& Deci, 2000) promote academic success (Greenwood, Horton \& Utley, 2002), but as Csikszentmihalyi (1997) identified, those involved in meaningful and challenging activities often achieve a sense of flow, recognised as contributing to individual happiness. If students are to be positively acknowledged by their peers as being capable within the classroom, it may be via activities that are meaningful to all. While it may be difficult to please all students in the classroom equally, a focus on a Universally Designed curriculum may be a useful approach (McGuire, Scott \& Shaw, 2006). Particularly important to Universal Design for Learning (UDL) is the multiple means of engagement advocated by the Centre for Applied Technology (CAST, 2011). The INT sub-scale item "My friends think I have good 
ideas", could only be achieved when students are engaged in classroom activities that are personally meaningful. O'Rourke and Houghton (2009) explored social engagement within inclusive classrooms, and indentified that it could be enhanced via meaningful and well structured activities. Such activities that create interest and enhance friendship opportunities appear vital to enhancing wellbeing.

\section{Conclusion}

It should be noted that there are specific limitations to this research and the findings need to be interpreted with caution. Firstly, participating schools and individuals (simply on the basis of their involvement) may have had positive viewpoints or at least an interest in the topic of happiness and this may have impacted on the results obtained from students, parents and teachers. Secondly, as outlined in O'Rourke and Cooper (2010) the make-up of the group was predominately English speaking parents and the need to complete a questionnaire to participate may have denied access to many. Finally, in any research involving self-reported happiness, researchers cannot be sure what students are referring to when asked to measure this feeling. Nevertheless, the use of reliable instruments such as the Piers-Harris 2, replication of Holder and Coleman's (2009) original research methodology, and findings consistent with the limited research set on happiness for this student group, provides positive (albeit tentative) evidence towards this emerging research area.

In closing, it would appear that discussions about enhancing happiness and wellbeing for our students appear to be just another item on a growing list of 'to dos' for classroom teachers. While some teachers may be reluctant to take on the responsibility that goes with developing and enhancing happiness, the findings presented in this paper suggest that the traditional foci of "behaviour and academic status" impacts on primary student wellbeing. Noble and McGrath's (2007) exploration of positive educational practices, highlights feelings aligned to student wellbeing such as; safety, satisfaction and pride, connectedness, enjoyment and fun, optimism, and a sense of being cared for (p. 3-4). Of these it is a true sense of connectedness with others and the curriculum that appears to be at the core of student's happiness and wellbeing. Malouf (2011) describing "the happy life" states; "Yes, it is true that we have little to complain of. Most of the conditions that might have made us 'miserable' have been legislated for and ameliorated. But the externals that govern our lives seem more alien and impersonal in their new form than in the old (p. 47-48)". Let us as educators ensure that we become far more personal and create a less alien curriculum for our students, and see this as a way forward.

\section{References}

Adler, N. (2002). Interpretations of the meaning of care: Creating caring relationships in urban middle school classrooms. Urban Education, 37(2), 241-266. http://dx.doi.org/10.1177/0042085902372005

Albert, L. (1996). Cooperative Discipline. Circle Plains, MN: American Guidance Service.

Alberto, P. A., \& Troutman, A. C. (2006). Applied behaviour analysis for teachers (7th ed.). New Jersey: Pearson.

Anderman, L. H. (2003). Academic and social perceptions as predictors of change in middle school students' sense of belonging. The Journal of Experimental Education, 72(1), 5-22. http://dx.doi.org/10.1080/00220970309600877

Anderson, S., Kerr-Roubineck, H., \& Rowling, L. (2006). Staff voices: What helps students with high mental health support needs connect to school? Australian Journal of Guidance \& Counselling, 16(1), 1-13. http://dx.doi.org/10.1375/ajgc.16.1.1

Associated Press \& MTV. (2007). Youth Happiness Survey. Retrieved from http://www.mtv.com/thinkmtv/about/pdfs/APMTV_happinesspoll.pdf

Baker, J. A., Lilly, L. A., Aupperlee, J. A., \& Patil, S. A. (2003). The developmental context of school satisfaction: Schools as psychologically healthy environments. School Psychology Quarterly, 18(2), 206-221. http://dx.doi.org/10.1521/scpq.18.2.206.21861

Brendtro, L., Mitchell, M., \& McCall, H. (2009). Deep brain learning: Pathways to potential with challenging youth. Albion, MI: Starr Commonwealth.

Brendtro, L., Brokenleg, M., \& Van Bockern, S. (2002). Reclaiming youth at risk: our hope for the future. Bloomington, Indiana: Solution Tree.

CAST. (2011). Centre for Applied Special Technology. About CAST. Retrieved from http://www.cast.org/about/

Csikszentmihalyi, M. (1997). Finding flow: The psychology of engagement with everyday life. U.S.A.: Perseus Books. 
Daniels, B., \& Arapostathis, J. (2005). What do they really want? Student voices and motivation research. Urban Education, 40(1), 34-59. http://dx.doi.org/10.1177/0042085904270421

De Neve, K. M., \& Cooper, H. (1998). The happy personality: A meta-analysis of 137 personality traits and $\begin{array}{lllll}\text { subjective well-being. } & \text { Psychological 197-229. }\end{array}$ http://dx.doi.org/10.1037/0033-2909.124.2.197

Diener, E., \& Diener, C. (1996). Most people are happy. Psychological Science, 7, 181-185. http://dx.doi.org/10.1111/j.1467-9280.1996.tb00354.x

Diener, E., \& Seligman, M. (2002). Very happy people. Psychological Science, 13, 81-84. http://dx.doi.org/10.1111/1467-9280.00415

Diener, E., \& Seligman, M. (2004). Beyond money: Toward an economy of wellbeing. Psychological Science in the Public Interest, 5(1), 1-31. http://dx.doi.org/10.1111/j.0963-7214.2004.00501001.x

Dockery, A. M. (2005). The happiness of young Australians: Empirical evidence on the role of the labour market experience. The Economic Record: The Economic Society of Australia, 81(255), 322-335. http://dx.doi.org/10.1111/j.1475-4932.2005.00272.x

Drolet, M., Paquin, M., \& Soutyrine, M. (2007). Strengths-based approach and coping strategies by parents whose young children exhibit violent behaviour: Collaboration between schools and parents. Child Adolescent Social Work, 24, 437-453. http://dx.doi.org/10.1007/s10560-007-0094-9

Elvin, H. L. (1965). Education and contemporary society. Oxford, UK: Alden Press.

Fetherston, A. (2008). Becoming an effective teacher. South Melbourne, Vic: Thomson.

Friend, M., \& Bursock, W. D. (2006). Including students with special needs. USA: Pearson Education.

Gilman, R., \& Huebner, E. S. (2006). Characteristics of adolescents who report very high life satisfaction. Journal of Youth and Adolescence, 35(3), 311-319. http://dx.doi.org/10.1007/s10964-006-9036-7

Gransden, B., \& Clarke, P. (2001). Student perceptions of factors impacting on their learning. Improving Schools, 4(1), 34-41. http://dx.doi.org/10.1177/136548020100400106

Greenwood, C. R., Horton, B. T., \& Utley, C. A. (2002). Academic engagement: Current perspectives on research and practice. School Psychology, 31(3), 328-350.

Heiman, T., \& Margalit, M. (1998). Loneliness, depression and social skills among students with mild mental retardation in special education and in mainstreamed classes. Journal of Special Education, 32(3), 154-163. http://dx.doi.org/10.1177/002246699803200302

Holder, M., \& Coleman, B. (2008). The contribution of temperament, popularity, and physical appearance to $\begin{array}{llll}\text { children's happiness. Journal of Happiness } & \text { 279-302. }\end{array}$ http://dx.doi.org/10.1007/s10902-007-9052-7

Holder, M., \& Coleman, B. (2009). The contribution of social relationships to children's happiness. Journal of Happiness Studies, 10, 329-349. http://dx.doi.org/10.1007/s10902-007-9083-0

Holder, M., \& Klassen, A. (2010). Temperament and Happiness in Children. Journal of Happiness Studies, 11(4), 419-439. http://dx.doi.org/10.1007/s10902-009-9149-2

Huebner, E. S., Gilman, R., \& Suldo, S. M. (2006). Life satisfaction. In G. Bear \& K. Minke (Eds.), Children's needs III (pp. 357-368). Bethesda, MD: National Association of School Psychologists.

Hyman, I. A. (1994). Policy and Practice in School Discipline: Past, Present and Future. Washington, DC: ERIC Document Reproduction Service (No. ED383960).

Lyubomirsky, S. (2001). Why are some people happier than others? The role of cognitive and motivational

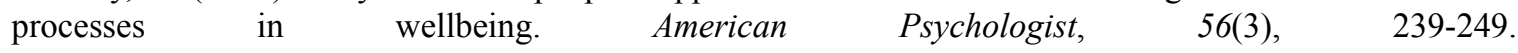
http://dx.doi.org/10.1037/0003-066X.56.3.239

Lyubomirsky, S. (2008). The how of happiness. A scientific approach to getting the life you want. New York, NY: Penguin Press.

Lyubomirsky, S., \& Lepper, S. (1999). A measure of subjective happiness: preliminary reliability and construct validation. Social Indicators Research, 46(2), 137-155. http://dx.doi.org/10.1023/A:1006824100041

Lyubomirsky, S., Caldwell, N. D., \& Nolen-Hoeksema, S. (1998). Effects of ruminative and distracting responses to depressed mood on the retrieval of autobiographical memories. Journal of Personality and 
Social Psychology, 75, 166-177. http://dx.doi.org/10.1037/0022-3514.75.1.166

Malouf, D. (2011). The happy life: The search for contentment in the modern world. Quarterly Essay 41: Black Inc.

McDonald, T. (2010). Classroom management: engaging students in learning. South Melbourne, Vic: Oxford.

McGorrey, P., Parker, A., \& Purcell, R. (2006). Youth mental health services. Australian Psychological Society. Retrieved from http://www.psychology.org.au/publications/inpsych/youth_mental_health/

McGuire, J. M., Scott, S. S., \& Shaw, S. F. (2006). Universal design and its applications in educational $\begin{array}{llll}\text { environments. Remedial and Special Education, 27(3), 166-175. } & \text {. }\end{array}$ http://dx.doi.org/10.1177/07419325060270030501

Michalos, A. (2008). Education, happiness and wellbeing. Social Indicators Research, 87, 347-366. http://dx.doi.org/10.1007/s11205-007-9144-0

Myers, D. G. (2000). The funds, friends, and faith of happy people. American Psychologist, 55, 56-67. http://dx.doi.org/10.1037/0003-066X.55.1.56

Myers, D. G., \& Diener, E. (1995). Who is happy? Psychological Science, 6, 10-19. http://dx.doi.org/10.1111/j.1467-9280.1995.tb00298.x

Myers, D. G., \& Diener, E. (1997). The science of happiness. The Futurist, 31(5), 1-7.

Nangle, D. W., Erdley, C. A., Newman, J. E., Mason, C. A., \& Carpenter, E. M. (2003). Popularity, friendship quantity and friendship quality: Interactive influences on children's loneliness and depression. Journal of Clinical Child and Adolescent Psychology, 32, 546-555. http://dx.doi.org/10.1111/j.1467-9280.1995.tb00298.x

Natvig, G. K., Albrektsen, G., \& Qvarnstrom, U. (2003). Associations between psychosocial factors and happiness among school adolescents. International Journal of Nursing Practice, 9, 166-75. http://dx.doi.org/10.1046/j.1440-172X.2003.00419.x

Newberry, M., \& Davis, H. A. (2008). The role of elementary teachers' conceptions closeness to students on their differential behaviour in the classroom. Teaching and Teacher Education, 24, 1965-1985. http://dx.doi.org/10.1016/j.tate.2008.02.015

Noble, T., \& McGrath, H. (2007). The positive educational practices framework: Leadership transforming schools through optimism. Paper presented at the ACEL/ASCD Conference: New Imagery for Schools and Schooling: Challenging, Creating, and Connecting, Sydney, Australia.

Noddings, N. (2003). Happiness and Education. New York, NY: Cambridge University Press. http://dx.doi.org/10.1017/CBO9780511499920

Oldfather, P. (1993). What students say about motivating experiences in whole language classroom. The Reading Teacher, 46(8), 672-681.

O'Rourke, J., \& Houghton, S. (2009). The perceptions of secondary teachers and students about the implementation of an inclusive classroom model for students with mild disabilities. Australian Journal of Teacher Education, 34(1), 23-41.

O'Rourke, J., \& Cooper, M. (2010). Lucky to be happy: A study of happiness in Australian primary students. Australian Journal of Educational \& Developmental Psychology, 10, 94-107.

Osterman, C. F. (2000). Students need for belonging in the school community. Review of Education Research, 70(3), 323-367.

Park, N., \& Peterson, C. (2006). Character strengths and happiness among young children: Content analysis of $\begin{array}{llllll}\text { parental descriptions. Journal of Happiness Studies, } & \text { 3, 34-341. }\end{array}$ http://dx.doi.org/10.1007/s10902-005-3648-6

Peterson, C., \& Seligman, M. E. P. (2004). Character Strengths and Virtues A Handbook and Classification. Washington, DC: APA Press and Oxford University Press.

Piers, E. V., \& Herzberg, D. S. (2002). Manual for the Piers-Harris Children's Self-Concept Scale (2nd Edition), Los Angeles: Western Psychological Services.

Pinto, T. (2006). The streaming of working class and minority students in Ontario. Our Schools, Our Selves, 15(2), 79-89. 
Proctor, C. L., Linley, P. A., \& Maltby, J. (2009). Youth life satisfaction: A review of the literature. Journal of Happiness Studies, 10, 583-630. http://dx.doi.org/10.1007/s10902-008-9110-9

Raymond, E. (2008). Learners with mild disabilities (3rd ed.). Boston, USA: Pearson.

Ryan, M. R., \& Deci, E. L. (2000). Intrinsic and extrinsic motivations: Classic definitions and new directions. Contemporary Educational Psychology, 25, 54-67. http://dx.doi.org/10.1006/ceps.1999.1020

Sargeant, J. (2010). The altruism of pre-adolescent children's (tweens) perspectives on "worry" and "happiness" in Australia and England. Childhood, 17(3), 411-425. http://dx.doi.org/10.1177/0907568209341087

Sawyer, M. G., Arney, F. M., Baghurst, P. A., Clark, J. J., Graetz, B. W., \& Kosky, R. J. et al (2000). The Mental Health of Young People in the Australia. Mental Health and Special Programs Branch. Commonwealth Department of Health and Aged and Care.

Schnall, S., Jaswal, V. K., \& Rowe, C. (2008). A hidden cost of happiness in children. Developmental Science, 11(5), 25-30. http://dx.doi.org/10.1111/j.1467-7687.2008.00709.x

Schraw, G., \& Aplin, B. (1998). Teacher preferences for mastery-oriented students. The Journal of Educational Research, 91, 215-20. http://dx.doi.org/10.1080/00220679809597546

Seligman, M. (1975). Helplessness: On depression, development, and death. San Francisco, USA: Freeman.

Seligman, M. (2002). Authentic happiness. USA: Free press.

Seligman, M. (2008, August). Positive education and the new prosperity: Australia's edge. Education Today.

Seligman, M., Ernst, R. M., Gillham, J., Reivich, K., \& Linkins, M. (2009). Positive education: positive psychology and classroom interventions. Oxford Review of Education, 35(3), 293-311. http://dx.doi.org/10.1080/03054980902934563

Seligman, M., Steen, T., Park, N., \& Peterson, C. (2005). Positive psychology progress: Empirical validation of interventions. American Psychologist, 60(5), 410-421. http://dx.doi.org/10.1037/0003-066X.60.5.410

Suldo, S. M., Riley, K. N., \& Shaffer, E. J. (2006). Academic correlates of children and adolescents' life $\begin{array}{lllll}\text { satisfaction. } & \text { School } & \text { Psychology } & \text { International, } & \text { 27(5), }\end{array}$ http://dx.doi.org/10.1177/0143034306073411

Stanley, F., Richardson, S., \& Prior, M. (2005). Children of the lucky country. Australia: MacMillan.

Stevens, C. (1977). (Remember the days of the old) School Yard. On Izitso [CD]. London, England: Island Records.

W. A. Curriculum Framework. (1998). Curriculum Framework: For Kindergarten to Year 12 Education in Western Australia. Perth, W.A: Curriculum Council.

Wallis, C. (2004, January). The new science of happiness. Time Magazine.

Weinstein, R. S., Marshall, H. H., Sharp, L., \& Botkin, M. (1987). Pygmalion and the student: Age and classroom differences in children's awareness of teacher expectations. Child Development, 58, 1079-1093. http://dx.doi.org/10.2307/1130548

Van Petegem, K., Aelterman, A., Rosseel, Y., \& Creemers, B. (2006). Student perception as moderator for student wellbeing. Social indicators Research, 83, 447-463. http://dx.doi.org/10.1007/s11205-006-9055-5

Woolfolk, A. (2011). Educational psychology (11th ed.). Boston, USA: Pearson. 